\title{
THE ROLE OF LOYALTY IN MIGRATION INTENTIONS: THEORY AND EVIDENCE FROM THE EU*
}

\author{
JÓZSEF GOLOVICS \\ Department of Comparative and Institutional Economics, \\ Corvinus University of Budapest, Hungary \\ E-mail: jozsef.golovics@uni-corvinus.hu
}

Free movement of persons is one of the fundamental values and achievements of the European Union, however, intentions towards mobility vary across and within the member states. Economic literature has remarkable theories to explain migration flows and individual selection factors of potential migrants, but it ignores major achievements of other social sciences. This paper builds an economic framework to incorporate the Hirschmanian concept of loyalty into the microeconomic (human capital) model of international migration by using interdependent preferences. Hirschman assumes that even after exiting, loyal people care about their previous communities, thus it imposes a certain psychological 'exit tax' on them. Based on this concept, it is hypothesized that people with altruistic motives have weaker intentions to migrate, so the presence of loyalty towards others makes international migration less likely, conveying that loyalty towards local or national community may be responsible for moderate labor mobility among EU member states. Results show that attachment to one's country makes one's intention to move abroad in the near future less likely, while loyalty towards one's city has more moderate impact on their intentions.

Keywords: migration, loyalty, altruism, EU

JEL-codes: F22, D00, D90

* This paper has been supported by the European Union and Hungary and co-financed by the European Social Fund through the project EFOP-3.6.2-16-2017-00017, entitled "Sustainable, intelligent and inclusive regional and city models." 


\section{INTRODUCTION}

Nowadays, international migration is an important and current issue both at a European and a global level. According to the UN (2017) there were 258 million international migrants worldwide in 2016. However, migration decisions in the $21^{\text {st }}$ century are characterized by a radically different environment than those in previous decades. Thanks to immense technological progress, the costs of mobility have dropped dramatically (Hoffmann 2010), and this was not accompanied by a similar decrease in international development disparities.

This environment influences potential migrants. Although various schools of the migration literature explain causes and main driving forces of migration differently (see Massey et al. 1993), none of them deny the importance of international disparities and the income gap, as well as the influential role of mobility costs. However, this implies that circumstances outlined above make migration a viable alternative for more and more people living in less developed countries.

The European Union is a spectacular example for this, inasmuch as achievements of the integration, regulation and other facilitation guarantee the freedom of movement for persons, which undoubtedly lessened mobility costs. Besides that, possibilities created by technological progress are also available. At the same time, development disparities are harshly present among old and new member states. As an example, country level data show an up to eight-fold difference in annual net earnings ${ }^{1}$ counted in euros and a two to three times gap can be seen even at purchasing power parity (Eurostat 2017).

Therefore, according to neoclassical economics - which predicts the flow of labor until the international equilibration of wages ${ }^{2}$ - intense waves of migration should have been witnessed in this relatively 'frictionless' institutional environment. However, despite any intentions or attempts of the European Commission (Andor 2014), intra-EU mobility is low. As an example for the puzzling phenomenon of this 'missing migration', only 3.0 percentage of European citizens lived in a member state other than their country of citizenship in 2016 (Eurostat 2018).

One cannot rule out the assumption that existing mobility costs are able to offset benefits of migration despite their extremely low level, however, another important factor remains unexplained. Although people typically move from Central East European (CEE) member states to the Western part of the EU, the extent of emigration affects CEE countries in a different way. Moreover, migra-

1 Disparities observed in annual net earnings are not exclusive indicators of differences in standard of living, but they correlate strongly with other relevant factors.

2 Although assumptions of these neoclassical models are not realistic, the EU can serve as the closest real-life example with its relatively 'frictionless' institutional framework. 
tion rates did not correlate with net annual earnings within this group between 2008 and 2013.

All the above-mentioned facts strengthen the empirical puzzle that development and earning disparities might be offset by other factors in potential migrants' cognitive framework. This paper hypothesizes that emotional ties, namely the presence of loyalty, is an important factor.

Loyalty is represented through psychic costs of migration in this paper. Mentioning the role of psychological costs of migration is not a novel idea in migration literature. Sjaastad (1962), pioneer of the human capital migration theory, also discusses the concept, however, he does not treat it as a real resource cost. Based on the idea that it is hardly measurable, he does not consider psychological costs as analitically usable components among the costs of migration. Other prominent scholars (e.g. Bauer - Zimmermann 1995; DaVanzo 1981; Massey et al. 1993) simply avoid detailed discussion of this factor, however, they name it as an important restraining force. Nonetheless, we argue that consideration of psychological costs can help to discover and understand the causes of the abovementioned 'missing migration' in today's changed migrational environment. In this regard, psychological aspects of migration are not treated as only a type of mobility cost. Instead, interdependent preferences and Hirschman's (1970) loyalty concept are used to incorporate these psychological ties into the microeconomic model of migration.

In order to test the role of loyalty empirically, we use individual Eurobarometer data on migration intentions from European Union member states. Loyalty is operationalized as a person's attachment to their city and country. We expect that beyond traditional selection factors (e.g. age, gender, family status, labor market status, etc.) loyalty ceteris paribus significantly decreases the probability of the intention to migrate. Similarly to previous papers (e.g. Fouarge - Ester 2008; Sik - Szeitl 2016; Zaiceva - Zimmermann 2008a) logit models are used in the estimation.

The paper is structured as follows. After the introductory section, we review the basic microeconomic background of migration in order to situate our theory in the existing literature (Section 2), then we build our theoretical model of migration considering loyalty (Section 3). After that, we present the dataset and methodology of our empirical test (Section 4). After demonstrating and discussing our results (Section 5), the paper comes to a conclusion. 


\section{THEORETICAL BACKGROUND}

This paper basically follows the tradition of the neoclassical microeconomic (or human capital) approach to migration (for further schools of migration theory see Massey et al. 1993). Thus, our unit of analysis is the individual and migration is viewed as an individual decision. As Becker (1962) emphasizes, people seek to economize rationally with their human capital: one might invest in it to gain maximal return. Based on Sjaastad's (1962) work, also theorized by Hart (1975) and Todaro and Maruszko (1987), migration is also a form of human capital investment. It has costs, but migrants are willing to undertake them in the hope of future benefits, which might lead to a better life in a foreign country. This investment decision is considered to be self-interested and preceded by rational cost-benefit calculation. Thus, potential migrants choose to leave their country of origin if benefits overwhelm costs of migration, and therefore it results in a net increase of benefits. In this calculation they consider international wage differences, standard of living disparities and labor market conditions. These market-type factors can be supplemented by further aspects that represent the governments' involvement in real economy (e.g. amount of taxes or public spending on unemployment benefits and other welfare expenditures). The net value of the latter is hereinafter referred to as net public service level.

The significant impact of the abovementioned factors on migration is verified in several empirical studies by using various methods at different levels. As for benefits, Ahman et al. (2008) proved the macro-level relevance of real wages and unemployment by using time-series from Pakistan. By using panel macro data from OECD countries, Mayda (2010) analyzed bilateral flows and found that wages and development (proxied by GDP) have a significant effect on migration. Sprenger (2013) analyzed intra-EU migration with panel methods and stressed the causal relationship between real economy conditions (per capita GDP, unemployment) and migration. Geis et al. (2008) focused on four developed countries and used multinomial logistic regression on micro data in order to prove that factors defining the net public service level in receiving countries also play an important role in migration decisions. Kureková (2013) used quantitative, as well as qualitative methods and found that the net public service level and welfare systems in countries of origin also affect intra-EU migration.

Benefits of migration may be balanced by its costs. These mobility costs consist of direct costs of travelling, moving and gathering information about job and accommodation opportunities as well as indirect costs such as opportunity cost of the latter actions or burdens of dealing with regulation (e.g. administrative duties imposed by immigration or visa policy), institutional, cultural and language differences. 
The significance of these costs on the migration decision was also tested empirically. Kim and Cohen (2010) proved the relevance of physical and linguistic distance by using panel methods in case of Western countries. Mayda (2010) and Sprenger (2013) demonstrated the importance of distance, costs of border crossing, language similarities and common cultural features while stressing the facilitating effect of institutions that guarantee the conditions of free labor flow. Palmer and Pytlikova (2015) used panel methods on European data and found a causal relationship between labor market regulations of receiving countries and the amount of immigration.

All of this can be formalized as follows. Consider the decision of a potential migrant who can choose between two alternatives where the above-mentioned costs and benefits are illustrated by proxy variables. Assume that their options are to stay in the country of origin or to move abroad. ${ }^{3}$ For the sake of simplicity, let us assume only one time period after migration where the related variables represent discounted net present values of all future flows of costs and benefits. As a result, in line with the aforementioned theoretical considerations and empirical evidences, an agent compares equations (1) and (2) in their cost-benefit calculation:

$$
\begin{gathered}
N B_{o}=\alpha_{o} I_{o}+G_{o}+\left(1-\alpha_{o}\right) U_{o}, \\
N B_{r}=\alpha_{r} I_{r}+G_{r}+\left(1-\alpha_{r}\right) U_{r}-C_{m},
\end{gathered}
$$

where $N B$ is net benefit of related alternatives, $I$ is income obtained from work, $G$ is net public service level, $U$ is unemployment benefit and $C_{m}$ is mobility cost. Furthermore, $\alpha$ is the probability of finding a job while $o$ and $r$ indices refer to country of origin and receiving country, respectively. It implies that migration is a rational choice for the agent if net benefit in the receiving country is higher than that in the country of origin. That is:

$$
N B_{r}>N B_{o} .
$$

For the sake of simplicity, assuming that actors certainly find a job in both countries (that is $\alpha_{r}=\alpha_{0}=1$ ) and defining $\Delta_{r}=I_{r}-I_{0}, \Delta G=G_{r}-G_{0}$ gives the following expression:

$$
\Delta I+\Delta G=C_{m}
$$

Although it may be strange to assume that potential migrants have two alternatives, a rational actor faces this kind of situation. Since a potential migrant with perfect information compares their situation with the best foreign alternative, therefore it is not necessary to consider more options. Nevertheless, it is a harsh constraint that may be loosened in further studies. For application of Simon's (1972) bounded rationality concept in migration theory, see Speare (1974). 
This implies that international differences in wages and net public service levels may be balanced by mobility costs. Although the operationalization and measurement of the latter in monetary terms is not unambiguous, it is undeniable that the amount of mobility costs dropped drastically in the last decades, thanks to immense technological progress. It follows that nowadays' extremely low mobility costs should incentivize rational actors towards migration in the presence of huge economic disparities.

In this context, it should be stressed that the economic literature outlined above is based on a mostly common idea: voluntary migration is driven by economic motives and it can be treated as a migrant's autonomous or individualistic decision (Collins 2018). And indeed, this approach undoubtedly explains a significant part of international migration. However, new considerations emerged from other disciplines of social sciences in order to understand contemporary migration in greater depth (Carling - Collins 2018). Besides that, the empirical puzzle outlined in Section 1 remains unexplained: why do people stay in their countries of origin despite the fact that migration would be beneficial for them in monetary terms? We argue that the incorporation of emotional factors would help to explain this 'missing migration'. This is in line with Carling and Collin's (2018: 913) argument which claims that 'drawing attention to emotions is critical to humanising migration'. Nevertheless, as opposed to their approach, we do this by extending the boundaries of the standard human capital model of migration. Existing literature also foreshadows this direction. However, while several authors (e.g. Bauer-Zimmermann 1995; DaVanzo 1981; De Jong - Fawcett, 1981; Massey et al. 1993) acknowledge the importance of psychological costs (due to the separation from relatives) among non-monetary costs of migration, they do not go into details about their ways of functionality. As an example, Sjaastad (1962) does not treat them as real resource costs so he does not include them into the costbenefit calculation. He argues that psychological costs are hardy measurable and are analogous to consumer surplus. Furthermore, it does not affect individual's choice above a certain level. Bodenhöfer (1967) uses the same argument as well. However, we disagree with this argument. In Section 3, we build a model that incorporates the actor's psychological ties into the model and thus gives a real sense for the psychological cost of migration.

\section{THE MODEL}

This model focuses on potential migrants' migration decisions. In the paper, migration is defined as a voluntary cross-border movement with the aim of longterm (more than one year) residential settlement. Our special interest concerns 
labor migration within the institutional framework of the European Union, which is still international migration, even though the aim of the European integration is the creation of a single labor market. Anyway, from a theoretical point of view, similar motivations lay behind both internal and international migration, and the only difference between them lies in their institutional framework (Bauer-Zimmermann, 1995). While the EU has major achievements in the field of the harmonization of formal institutions, legal differences do exist, and informal institutions, norms, cultural conventions are still very diverse. The definition above implies that commuting and other types of short-term movements are omitted from this paper. Although these actions may also have similar driving forces, psychological costs derived from emotional ties occur mostly in case of long term migration.

In this context, our model is directly built on the one described in Section 2. We thus follow the Sjaastadian tradition, which is called the neoclassical microeconomic theory of migration (Massey et al. 1993), standing on the basis of methodological individualism. However, as it has been emphasized by other disciplines of social sciences, desire to migrate and the act of migration cannot be understood without its wider social context (Collins 2018). Therefore, we put a special emphasis on the social environment of the migration decision. Man is a 'social creature', thus people get in touch with each other, they influence each other and they care about others. The circle of care might be narrowed in some cases (e.g. restricted to the family), while others might care about their wider environment (e.g. neighborhood or the whole society). It often results in people not seeking their self-interest but considering the welfare of others, which is the case of altruism.

Although altruism contradicts the basic behavioral assumption of economics, it has become an ordinary concept - with a huge amount of empirical evidence - in mainstream economics as well. It also means that several forms and interpretations of it have been outlined in the economic literature (Golovics 2015). In this study, altruism is introduced into the model by using Pollak's (1976) interdependent preferences concept. This manifestation of altruism was elaborated in Becker's $(1974 ; 1976)$ work and also applied by Ishikawa (1975), Bolnick (1979), Rapoport (1995) and Ottoni-Wilhelm et al. (2017). In these types of models, other people's welfare may also be included in the altruist's utility function, which means that considering others' interest is also part of the agent's maximization problem. However, it should be emphasized that interdependence of utility functions is not derived from an externality generated by someone's action but based on interpersonal relations (Choi 1993; Hámori 2003).

Thus, in our model, a potential migrants' welfare depends not only on their own utility but also on changes in others' utility related to them: 


$$
U_{i}=U_{i}\left(N B_{i} ; \gamma_{x} \Delta S U_{x} ; \gamma_{y} \Delta S U_{y} ; \gamma_{z} \Delta S U_{z} ; \ldots\right),
$$

where $U_{i}$ is the agent's utiliy, $N B_{i}$ is their net benefit level resulting from the migration decision, $\Delta S U$ is the agent's 'social utility' factor that embodies changes in others' utility about whom agent cares. Indices $x, y, z$ refer to these related people, while $\gamma$ measures the strength of their relationship.

These types of altruistic relationships are defined as loyalty in this paper and it can be applied towards any person or group. It signifies that we consider a person loyal if they have any of this kind of altruistic relationship. Existence and the extent of these altruistic relationships may vary among the members of society but they are considered to be exogenously given for each individual at the time of migration decision making. ${ }^{4}$

In this context, loyalty is a more complex factor than a simple type of mobility cost, labelled as a psychological cost in the previous literature. The latter merely refers to welfare loss generated by breaking-up interpersonal ties. However, the loyalty concept of this study also takes the fact into account that loyal people include each kind of change in related people's welfare generated by their migration in their own utility function. The sign of change may also be positive in the case when the aim of migration is to find a better job abroad in order to help family left behind with remittances - which is also an altruistic and 'loyal' motive.

The loyalty concept defined above can be connected to Hirschman's (1970) 'exit-voice-loyalty theory' as well. According to Hirschman, a person has two choices in case of dissatisfaction (e.g. with an organization membership, consumption of a product or living in a country): i) they can choose an exit strategy by quitting the situation; or ii) they can give voice to their dissatisfaction while staying in the situation. As Mike (2012: 59) stresses, 'exit and voice may be substitutes or complements', hence dissatisfied individuals' choice depends not just on circumstances and characteristics of the situation but on their loyalty, too. Thus, loyalty functions as an equilibrating factor inasmuch as its existence makes the choice of exit less likely.

The applicability of Hirschman's concept in migration theory has already been raised in several papers, including Hirschman (1978) himself; however, none of them reaches the stage of formal modelling. While Ruget and Usmanalieva (2008) discuss the role of loyalty only in general terms, Schewel (2015) and Carling and Schewel (2018) mention loyalty as a non-economic retaining factor, Newland

4 Although this paper treats loyalty as an exogenous factor for reasons of space, the existence and the extent of loyalty could be connected to the individual's previous life. For a detailed discussion about the connection between loyalty and previous specific investments, see Mike (2012). 
(2010), Johnston (2011) and Burgess (2012) examine the effect of emigrants on the politics of their country of origin with qualitative tools, Hoffmann (2010) inquires the empirical applicability and a possible extension of Hirschman's terminology in connection with international migration.

The identity of Hirschman's loyalty concept with the one defined in this paper is manifested in its effect on a migrant's utility. In Hirschman's (1970) theory, loyal people do not ignore the fate of their former communities. And if they know that their exit aggravates the community's decline, they internalize it as an 'exit tax'. Effect of the latter is equivalent to that of loyalty defined in this paper: a welfare change in the actor's utility function. A related person's psychological pain generated by the cessation of daily connections or the negative fiscal externality ${ }^{6}$ born by the society of the home country can be mentioned as types of welfare losses, while the assisting force of remittances could be a form of welfare gain in concern. Nonetheless, it should be emphasized that 'loyalty tax' in our model is only triggered if related people's welfare changes due to migration. Thus, it does not come into effect if family members also migrate with the actor.

All of this can be incorporated into the model outlined above by introducing a loyalty factor in a potential migrant's utility function. Therefore, if the potential migrant is loyal (i.e. at least one of $\gamma_{i} \neq 0$ (where $i=x, y, z, \ldots$ ) in expression (5)), then loyalty factor $L$ is added to their net benefits in case of migration which is given (6) below. ${ }^{7}$ This loyalty factor $L$ embodies the net of welfare changes from all the altruistic relationships that the actor possesses. ${ }^{8}$

$$
N B_{r}=\alpha_{r} I_{r}+G_{r}+\left(1-\alpha_{r}\right) U_{r}-C_{m}+L
$$

where $L=\sum_{i} \gamma_{i} \Delta S U_{i}$ and $(i=x, y, z, \ldots)$.

5 This concept is similar to Simon's (1990) idea, who argued that society tends to tax docile persons by making them perform altruistic acts.

6 Fiscal externality refers to a situation where local public goods are financed by local taxes. In this case, residential decisions (i.e. moving to another municipality) change the tax base in cities in concern and, as a result, local governments should change tax rates to maintain the former level of public goods or equivalently, adjust the level of public goods provision to the new level of tax revenues (Wildasin 1989; Hercowitz - Pines 1991). In case of a person's migration, this effect is marginal. However, in case of mass emigration, negative fiscal externality effects can be extremely dangerous.

7 It means that in the case of a disloyal person, $L=0$.

8 Although, one might argue that the loyalty factor (multiplied either by the same or by another parameter) should be included in the potential migrant's net benefit function in case of staying as well, this technique is not applied in this paper. It can be interpreted as follows: migration may reduce individual's welfare through their altruistic relations but staying does not provide any welfare surplus. 
In this form, the loyalty factor represents a feedback from related persons' welfare changes through altruistic bonds. It can be interpreted in a way that a loyal individual has such connections with other persons (e.g. friends, family members, community, society) that changes in the latter's welfare (either positive or negative), have a welfare effect on their own utility with the same sign. And although loyalty is hard to operationalize or express in monetary terms, our proposition is that loyalty can deter potential migrants from going abroad if:

$$
\Delta I+\Delta G-C_{m}+L<0 .
$$

This suggests that if the net of wage differences, public service level differences and mobility costs supplemented by welfare change expressed through loyalty factor is negative, then potential migrants choose to stay in the country of origin. Thus, loyalty can offset the attractiveness of migration in the presence of huge development disparities and low mobility costs. As a result, it may explain the "missing migration" puzzle raised in Section 1. Consequently, loyalty towards the family, the community or the society of the country of origin may be the reason why masses of EU citizens (mostly from new member states) do not choose to live in another member state where the standard of living and labor market opportunities are better, despite low mobility costs and institutionally guaranteed freedom.

\section{DATA AND METHODOLOGY}

In order to empirically test our hypothesis about the role of loyalty in migration decisions, we use Eurobarometer survey data and estimate a logistic regression model. The main characteristics of the dataset and the exact specification of empirical model are detailed below.

In compliance with our microeconomic theoretic model, micro level data is used in empirical tests in order to avoid ecological fallacy. We use individual data from Eurobarometer 73.3 (Mar-Apr 2010), which is an EU-wide representative survey that contains answers from 26,602 respondents (European Commission 2012). The survey comprises ordinary questions about respondents' socioeconomic backgrounds, while it contains thematic blocks as well. One of these thematic blocks was about the respondent's mobility history and intentions. This wave of Eurobarometer surveys included questions about the respondents' attachment to different entities as well. This combination of questions makes it possible to empirically test our migration model supplemented with loyalty while controlling for standard socio-economic variables. 
Our dependent variable is based on the respondents' answer about their migration intention in the next ten years. ${ }^{9}$ Although statements about future intentions are not equivalent to actual migration, using migration intention data in empirical studies is an ordinary practice in migration research (see e.g. Fouarge - Ester 2008; Sik - Szeitl 2016) because of the "high correlation between migration intentions and their realization" (Zaiceva - Zimmermann 2008a: 439). Blanchflower et al. (2007) and Zaiceva and Zimmermann (2008b) showed that characteristics of people who intend to migrate and those of actual migrants are quite similar. Sik and Szeitl (2016) confirmed these similarities. Furthermore, Böheim and Taylor (2002) found that people with previous preference to move are far more likely to go abroad than others. There are practical reasons too for using migration intention data. First, researchers face serious difficulties in conceptualization, measurement and registration of migration (for details see Bauer - Zimmermann 1995), which results in a lack of cross-country micro data about migration, therefore finding a reliable and representative dataset that includes personal attributes of migrants and contains these pieces of information about a representative reference group, too, (i.e. people who did not emigrate) is hardly possible. Secondly, as Bauer and Zimmermann (1995) emphasize, actual migrants represent only a very small part of society which may raise problems in estimation, therefore using migration intention data may lighten this inconvenience (i.e. people with migration intentions represent a bigger fraction of society). Consequently, although migration intention data overestimates potential migration, it can be considered as a sufficient tool to empirically analyze motivations behind migration decisions.

In our empirical specification the dependent variable is a dummy, which means that we grouped respondents' answer as follows: 1 if they intend to migrate (very likely, fairly likely), 0 if they do not intend to migrate (not very likely, not at all likely). If the dependent variable equals 1 , then the person is defined to be a potential migrant. Figure 1 reports the proportion of potential migrants per country.

Our focal independent variables serve as proxies for the different aspects of a person's loyalty. For that, we use answers for survey questions about the respondents' attachment to their countries (Loyalty/country) and to their cities/towns/ villages (Loyalty/city). Answers are coded as follows: 1: not attached at all; 2: not very attached; 3 : fairly attached; 4 : very attached. We expect that stronger attachment represents stronger altruism towards the community or society of the entity in concern, which means that one has less intention to migrate.

The exact wording of the question is the following: 'How likely do you think it is that you will move to another country within the next ten years, to live there?' 


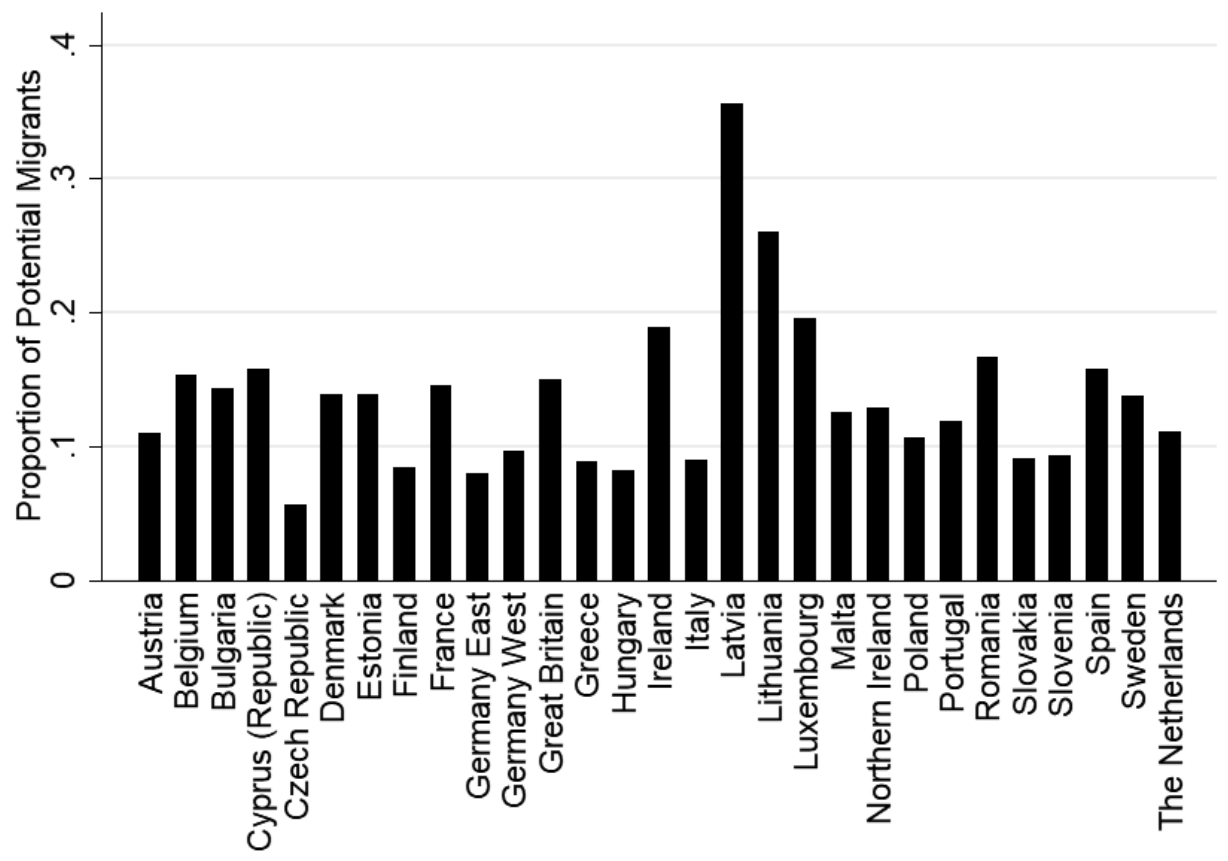

Figure 1. Proportion of potential migrants in EU member states (2010)

Source: European Commission (2012).

Dummies indicating marital status are also used as independent variables (Living with partner, Single, Divorced, Widow, where reference group is Married). Number of children under 15 (Children) is also an important characteristic. Both Becker (1974) and Simon (1993) claim that family is the basis of altruistic relationships because of sociobiological reasons, so we expect that people with bigger and institutionalized families are less likely to migrate.

A respondent's minority identity in religious, cultural or ethnic dimension (Minority) is another independent dummy variable. Simon (1993) claims that minority groups tend to teach their docile members to behave altruistically towards other group members, thus, the feeling of belonging to a minority group in terms of religion, culture or ethnic origin is expected to mitigate migration intentions.

Age is a common control variable in a microeconomic migration model since older people have a shorter time horizon on which they can maximize the lifetime welfare gain of migration. Besides that, Lowe and Ritchey's (1973) empirical investigation found that older people have more altruistic attitudes than younger people, consequently, there may be a correlation between age and altruistic 
loyalty, so it can be assumed that an increase in age decreases the probability of migration.

Furthermore, we use further control variables that are common in migration literature (see Fouarge - Ester 2008; Sik - Szeitl 2016 and Zaiceva - Zimmermann 2008a). Homeowners and homeowners with mortgage are expected to be less likely to migrate since their houses serve as a location specific investment. More-educated people (Education) are expected to have higher migration intentions as their human capital is utilized easier in foreign countries too, so they have a higher probability of finding a job. The same argument can be applied for those people who are fluent in a foreign language (Language). Foreign language speakers can also seek information with less transaction costs. Internet usage (Internet) also eases information gathering so people who use the internet more often are expected to have higher migratory potentials. Since migration networks facilitate migration significantly (Massey 1990), it can be expected that people with relatives (Network/relatives) or friends (Network/friends) abroad are more likely to migrate. The same is expected for those who have previous migratory history: i.e. worked abroad (Network/work), studied abroad (Network/study), lived abroad (Network/live) or regularly go abroad (Network/ go). To control financial status, a dummy variable (Financial status) is used that indicates whether the respondent had difficulties in paying their bills at the end of the month in the last twelve months. Because of sociological reasons, we also control for respondents' gender (Male), inhabitancy (Small town and Large town) and labor market status (Unemployed, Retired, Student, Self-employed). Finally, a dummy (EU15) is used to control for different macroeconomic and institutional backgrounds of old and new member states. Descriptive statistics for the variables are in Appendix Table A1.

In order to estimate the model, a logistic regression is used. Since our dependent variable is qualitative, simple OLS assumptions do not hold. Because of this, the usage of OLS (a so called linear probability model) may predict probabilities higher than 1. However, based on its properties, a logit model is an appropriate one for our estimation. Because of the problem of heteroscedasticity, robust standard errors are used. Our empirical strategy is to estimate a basic model (Specification 1) with ordinary independent variables and another one with supplemented proxies of loyalty (Specification 2). Eventually, we compare them. Goodness of fit is measured by the models' pseudo R-squared and their ability to correctly predict values. 


\section{RESULTS}

Table 1 presents results from estimating Specification 1 and Specification 2. It shows marginal effects for the migration intentions related to the intentions to stay in the respondents' home country.

Results show that most of our variables turned to be significant in both specifications and they are in line with general human capital theory of migration. Signs and magnitudes of coefficients are similar to those of previous studies (e.g. Fouarge - Ester 2008; Sik - Szeitl 2016; Zaiceva - Zimmermann 2008a) as well. Older people are less likely to migrate and owning a house (either with mortgage or without it) also decreases the willingness to migrate. Potential migrants are positively selected with respect to education, language knowledge and internet usage. Network effects also matter: having relatives or friends abroad and previous foreign experiences increase the probability of migration. Those who have difficulties with paying the bills are more willing to migrate, which indicates that financial reasons may be important driving forces of migration. Willingness to migrate is higher among male respondents and people living in towns. Labor market status variables are also in line with expectations: unemployed people and students are more likely to migrate, while retired respondents have lower migration intentions. Being employed does not have a significant effect on the willingness to migrate compared to being self-employed in either specification. Citizens from old EU member states are less willing to migrate, which can be explained by better macroeconomic conditions, standards of living as well as different institutional backgrounds.

Besides that, loyalty also matters in shaping migration intentions. People who are loyal towards their country or city are significantly less willing to migrate. In this regard, loyalty towards country has a higher impact. Altruistic considerations towards family members may also matter. People with more children are less likely to migrate, while being single or divorced increases the probability of migration. Living with a partner or being widowed has a statistically insignificant effect on migration intentions compared to that of married respondents. Belonging to a minority group turned out to be significant, however, its impact on willingness to migrate contradicts our expectations: members of minority groups have larger intentions to migrate. The reason behind it may be complex. On the one hand, as DaVanzo (1981) emphasizes, former migration experiences foster repeated migration. Thus, the supposition that members of minority groups may be immigrants can be an explanation for their higher willingness to migrate. The fact that minorities tend to be displaced to the periphery of society may also enhance migration intentions. In this respect, note that altruism may foster emi- 
Table 1. Determinants of migration intentions in the EU. Marginal effects from Logit model

\begin{tabular}{|c|c|c|c|c|}
\hline \multirow[b]{3}{*}{ Loyalty/country } & \multicolumn{2}{|c|}{ Specification 1} & \multicolumn{2}{|c|}{ Specification 2} \\
\hline & \multicolumn{4}{|c|}{ Migration intention } \\
\hline & & & $-0.0252 * * *$ & $(0.00238)$ \\
\hline Loyalty/city & & & $-0.0118^{* * *}$ & $(0.00206)$ \\
\hline Living with partner & & & 0.00850 & $(0.00518)$ \\
\hline Single & & & $0.0222 * * *$ & $(0.00500)$ \\
\hline Divorced & & & $0.0168 * *$ & $(0.00735)$ \\
\hline Widow & & & 0.00367 & $(0.0107)$ \\
\hline Children & & & $-0.00959 * * *$ & $(0.00179)$ \\
\hline Minority & & & $0.0278 * * *$ & $(0.00566)$ \\
\hline Age & $-0.00298 * * *$ & $(0.000145)$ & $-0.00260 * * *$ & $(0.000165)$ \\
\hline Homeowner & $-0.0234 * * *$ & $(0.00366)$ & $-0.0134 * * *$ & $(0.00384)$ \\
\hline $\begin{array}{l}\text { Homeowner with } \\
\text { mortgage }\end{array}$ & $-0.0253 * * *$ & $(0.00313)$ & $-0.0166 * * *$ & $(0.00349)$ \\
\hline Education & $0.000826^{* *}$ & $(0.000321)$ & $0.000709^{* *}$ & $(0.000327)$ \\
\hline Language & $0.0180 * * *$ & $(0.00319)$ & $0.0121 * * *$ & $(0.00332)$ \\
\hline Internet & $0.00309 * * *$ & $(0.000736)$ & $0.00365^{* * *}$ & $(0.000809)$ \\
\hline Network/relatives & $0.0239 * * *$ & $(0.00341)$ & $0.0235 * * *$ & $(0.00363)$ \\
\hline Network/friends & $0.0524 * * *$ & $(0.00349)$ & $0.0499 * * *$ & $(0.00371)$ \\
\hline Network/work & $0.0434 * * *$ & $(0.00555)$ & $0.0421 * * *$ & $(0.00584)$ \\
\hline Network/study & $0.0187 * * *$ & $(0.00580)$ & $0.0120 * *$ & $(0.00579)$ \\
\hline Network/live & $0.0408 * * *$ & $(0.00648)$ & $0.0338 * * *$ & $(0.00661)$ \\
\hline Network/go & $0.0180 * * *$ & $(0.00383)$ & $0.0119 * * *$ & $(0.00384)$ \\
\hline Financial status & $0.0271 * * *$ & $(0.00326)$ & $0.0255 * * *$ & $(0.00353)$ \\
\hline Male & $0.0184 * * *$ & $(0.00290)$ & $0.0125^{* * *}$ & $(0.00306)$ \\
\hline Small town & $0.0120 * * *$ & $(0.00358)$ & $0.00856^{* *}$ & $(0.00374)$ \\
\hline Large town & $0.0171 * * *$ & $(0.00387)$ & $0.0118 * * *$ & $(0.00403)$ \\
\hline Unemployed & $0.0201 * * *$ & $(0.00701)$ & $0.0164 * *$ & $(0.00734)$ \\
\hline Retired & $-0.0171 * *$ & $(0.00688)$ & $-0.0210^{* * *}$ & $(0.00702)$ \\
\hline Student & $0.0745 * * *$ & $(0.0117)$ & $0.0483 * * *$ & $(0.0109)$ \\
\hline Employed & 0.00164 & $(0.00536)$ & -0.00226 & $(0.00554)$ \\
\hline EU15 & $-0.00958 * * *$ & $(0.00322)$ & $-0.0114 * * *$ & $(0.00350)$ \\
\hline Pseudo $\mathrm{R}^{2}$ & 0.2385 & & 0.2649 & \\
\hline Observations & 25,230 & & 20,139 & \\
\hline
\end{tabular}

Notes: Robust standard errors in parentheses. Significances: $* * * \mathrm{p}<0.01, * * \mathrm{p}<0.05, * \mathrm{p}<0.1$. Reference groups are married, not owning a house, not feeling belonging to a minority group, not speaking any language fluently, not having any network abroad, not having financial difficulties at paying the bills, female, rural area, self-employed.

Source: author's calculations based on European Commission (2012). 
gration if the individual would be able to help the family by moving to another country which is in line with our theoretical model.

As a result, loyalty contributes to increasing the explanatory power of the standard microeconomic model of migration. By adding proxies of loyalty, no standard variable changes its sign or loses its significance. Pseudo R-squared of Specification 2 is 2.64 percentage points higher than that of Specification 1, which is a moderate difference, however, note that Logit models do not tend to have high Pseudo R-squared values in empirical studies. ${ }^{10}$ Concerning the predictive power of the model, Specification 2 is able to correctly classify 88.27 percentage of observations by using a cutoff point at 0.5 (which is also a moderate increase if we consider that Specification 1 is able to correctly classify 87.44 percentage of observations). Nevertheless, incorporating loyalty into the model enhances its explanatory power even if it is a slight increase.

Although these results support the argument that loyalty matters in shaping migration intentions, our empirical investigation has limitations. Survey data has been taken in 2010, after the financial crisis, so special distortion may be present in the data set. Besides that, although using migration intention data is an ordinary practice in migration literature, it has to be emphasized that articulation of intention to migrate is only a necessary but not sufficient condition to actual migration. As Carling and Schewel (2018) and Gödri and Feleky (2017) argue, certain barriers may prevent actual migration even if one aspires to move. Consequently, further research - if it is possible - is needed on actual migration data in order to test the robustness of our results.

\section{CONCLUSIONS}

This paper focused on the determinants of individual migration decisions. Although neoclassical human capital theory of migration has major achievements in this field, its explanatory power is unsatisfactory since it ignores many psychological aspects of the decision as well as the well-known fact that people feel like belonging to a certain community. Thus, this paper aimed at building a theoretical framework that incorporated loyalty into the microeconomic theory of migration. In this regard, a plausible and well-grounded theoretical model was built that was able to provide a reason for the unexplained 'missing' migration in the European Union.

10 See Sik and Szeitl (2016) or Zaiceva and Zimmermann (2008a), where pseudo R-squared values tend to move between 0.10 and 0.21 . 
Our model was tested empirically on migration intentions data. Although variables used in the empirical model are not entirely novel in migration studies, this time they were supported by a solid economic model that is perfectly compatible with neoclassical human capital theory. Estimations show that loyalty indeed matters in shaping people's willingness to migrate, however, robustness of results could be enhanced if better data were available. Nonetheless, the analysis in this paper showed that the presence of altruistic ties and loyalty towards individuals' community may make them to stay in their country of origin even though migration would be a rational alternative from a financial point of view.

Results of this paper open new perspectives in migration studies. On the one hand, our hypothesis could be tested on other types of datasets (e.g. about actual migration or with higher variance in the dependent variable). On the other hand, it sheds another light on existing literature. In line with migration network theory (Massey 1990), altruistic relationships defined in this paper may also strengthen one's willingness to migrate if one's loved ones have already migrated. However, it seems to contradict the theory outlined above, and the truth is that 'net utility' from emotional bonds play an important role in migration choices. Finally, this paper re-opens the question about self-interest and raises questions about the origins of altruism in order to understand the very nature of human decisionmaking.

\section{REFERENCES}

Ahmad, N. - Hussain, Z. - Sial, M. H. - Hussain, I. - Akram, W. (2008): Macroeconomic Determinants of International Migration from Pakistan. Pakistan Economic and Social Review 46(2): 85-99.

Andor, L. (2014): Labour Mobility in the European Union - The Inconvenient Truth. Lecture at University of Bristol, Bristol. http://europa.eu/rapid/press-release_SPEECH-14-115_en.htm, accessed 13/11/2017.

Bauer, T. - Zimmermann, K. (1995): Modelling International Migration: Economic and Econometric Issues. In: van der Erf, R. - Heering, L. (eds): Causes of International Migration. Proceedings of a Workshop. Luxembourg: Eurostat, pp. 95-115.

Becker, G. S. (1962): Investment in Human Capital: A Theoretical Analysis. Journal of Political Economy 70(5): 9-49.

Becker, G. S. (1974): A Theory of Social Interactions. Journal of Political Economy 82(6): 10631093.

Becker, G. S. (1976): Altruism, Egoism, and Genetic Fitness: Economics and Sociobiology. Journal of Economic Literature 14(3): 817-826.

Blanchflower, D. G.- Saleheen, J. - Shadforth, C. (2007): The Impact of the Recent Migration from Eastern Europe on the UK Economy. IZA Discussion Paper No. 2615.

Bodenhöfer, H. J. (1967): The Mobility of Labor and the Theory of Human Capital. The Journal of Human Resources 2(4): 431-448. 
Bolnick, B. R. (1979): Government as a Super Becker-Altruist. Public Choice 34(3): 499-504.

Böheim, R. - Taylor, M. P. (2002): Tied Down or Room to Move? Investigating the Relationships between Housing Tenure, Employment Status and Residential Mobility in Britain. Scottish Journal of Political Economy 49(4): 369-392.

Burgess, K. (2012): Migrants, Remittances, and Politics: Loyalty and Voice after Exit. The Fletcher Forum of World Affairs 36(1): 43-55.

Carling, J. - Collins, F. (2018): Aspiration, Desire and Drivers of Migration. Journal of Ethnic and Migration Studies 44(6): 909-926.

Carling, J. - Schewel, K. (2018): Revisiting Aspiration and Ability in International Migration. Journal of Ethnic and Migration Studies 44(6): 945-963.

Choi, Y. B. (1993): Paradigms and Conventions. Uncertainty, Decision Making, and Entrepreneurship. Ann Arbor: The Universitiy of Michigan Press.

Collins, F. L. (2018): Desire as a Theory for Migration Studies: Temporality, Assemblage and Becoming in the Narratives of Migrants. Journal of Ethnic and Migration Studies 44(6): 964980.

DaVanzo, J. (1981): Microeconomic Approaches to Studying Migration Decisions. In: De Jong, G. F. - Gardner, R. W. (eds): Migration Decision Making. Multidisciplinary Approaches to Microlevel Studies in Developed and Developing Countries. New York: Pergamon Press, pp. 90129.

De Jong, G. F. - Fawcett, J. T. (1981): Motivations for Migration: An Assessment and a ValueExpectancy Research Model. In: De Jong, G. F. - Gardner, R. W. (eds): Migration Decision Making. Multidisciplinary Approaches to Microlevel Studies in Developed and Developing Countries. New York: Pergamon Press, pp. 13-58.

European Commission (2012): Eurobarometer 73.3 (Mar-Apr 2010). TNS OPINION \& SOCIAL, Brussels [Producer]. GESIS Data Archive, Cologne. ZA5233 Data file Version 3.0.0. https://dbk. gesis.org/dbksearch/sdesc2.asp?no=5233\&db=e\&doi=10.4232/1.10114, accessed 01/12/2016.

Eurostat (2017): Annual Net Earnings (earn_nt_net). Eurostat Database. http://appsso.eurostat. ec.europa.eu/nui/show.do?dataset=earn_nt_net, accessed 02/12/2017.

Eurostat (2018): Population on 1 January by Five Year Age Group, Sex and Citizenship [migr pop1ctz]. Eurostat Database. http://appsso.eurostat.ec.europa.eu/nui/show.do?dataset=migr_ poplctz\&lang=en, accessed 09/02/2018.

Fouarge, D. - Ester, P. (2008): How Willing are Europeans to Migrate? A Comparison of Migration Intentions in Western and Eastern Europe. In: Ester, P. - Muffels, R. - Schippers, J. - Wilthagen, T. (eds): Innovating European Labour Markets. Cheltenham: Edward Elgar, pp. 49-71.

Geis, W. - Uebelmesser, S. - Werding, M. (2008): How do Migrants Choose Their Destination Country? CESifo Working Paper No. 2506.

Gödri, I. - Feleky, A. (2017): Selection of Migrants and Relization of Migration Intentions - Lessons from a Panel Study. Hungarian Demographic Research Institute Working Papers on Population, Family and Welfare No. 29.

Golovics, J. (2015): Bounded Rationality and Altruism: Behaviourism in Economics. Financial and Economic Review 14(2): 158-172.

Hámori, B. (2003): Érzelemgazdaságtan [Economics of Emotions]. Budapest: Kossuth Kiadó.

Hart, R. A. (1975): Interregional Economic Migration: Some Theoretical Considerations (Part II). Journal of Regional Science 15(3): 289-300.

Hercowitz, Z. - Pines, D. (1991): Migration with Fiscal Externalities. Journal of Public Economics 46(2): 163-180.

Hirschman, A. O. (1970): Exit, Voice, and Loyalty: Responses to Decline in Firms, Organizations, and States. Cambridge: Harvard University Press. 
Hirschman, A. O. (1978): Exit, Voice, and the State. World Politics 31(1): 90-107.

Hoffmann, B. (2010): Bringing Hirschman Back In: "Exit", "Voice", and "Loyalty" in the Politics of Transnational Migration. The Latin Americanist 54(2): 57-73.

Ishikawa, T. (1975): Family Structures and Family Values in the Theory of Income Distribution. Journal of Political Economy 83(5): 987-1008.

Johnston, T. (2011): Voice after Exit? Remittances and Migration across Authoritarian Regimes. UM Comparative Politics Workshop, January 28, 2011. https://sites.lsa.umich.edu/tsebelis/wpcontent/uploads/sites/223/2015/01/johnston.cpw2011.pdf, accessed 02/11/2017.

Kim, K. - Cohen, J. E. (2010): Determinants of International Migration Flows to and from Industrialized Countries: A Panel Data Approach Beyond Gravity. International Migration Review 44(4): 899-932.

Kureková, L. (2013): Welfare Systems as Emigration Factor: Evidence from the New Accession States. Journal of Common Market Studies 51(4): 721-739.

Lowe, R. - Ritchey, G. (1973): Relation of Altruism to Age, Social Class, and Ethnic Identity. Psychological Reports 33(2): 567-572.

Massey, D. S. (1990): Social Structure, Household Strategies, and the Cumulative Causation of Migration. Population Index 56(1): 3-26.

Massey, D. S. - Arango, J. - Hugo, G. - Kouaouci, A. - Pellegrino, A. - Taylor, E. J. (1993): Theories of International Migration: A Review and Appraisal. Population and Development Review 19(3): 431-466.

Mayda, A. M. (2010): International Migration: A Panel Data Analysis of the Determinants of Bilateral Flows. Journal of Population Economics 23(4): 1249-1274.

Mike, K. (2012): Hirschman Meets Williamson: Relationship-Specific Investment and Loyalty. Corvinus Journal of Sociology and Social Policy 3(2): 55-81.

Newland, K. (2010): Voice After Exit: Diaspora Advocacy. Washington, DC: Migration Policy Institute. https://www.migrationpolicy.org/pubs/diasporas-advocacy.pdf, accessed 02/11/2017.

Ottoni-Wilhelm, M. - Vesterlund, L. - Xie, H. (2017): Why do People Give? Testing Pure and Impure Altruism. American Economic Review 107(11): 3617-3633.

Palmer, J. - Pytlikova, M. (2015): Labor Market Laws and Intra-European Migration: The Role of the State in Shaping Destination Choices. European Journal of Population 31(2): 127-153.

Pollak, R. A. (1976): Interdependent Preferences. The American Economic Review 66(3): 309320.

Rapoport, H. (1995): Coordination, Altruism and Under-Development. Kyklos 48(3): 389-407.

Ruget, V. - Usmanalieva, B. (2008): Citizenship, Migration and Loyalty towards the State: A Case Study of the Kyrgyzstani Migrants Working in Russia and Kazakhstan. Central Asian Survey 2: 129-141.

Schewel, K. (2015): Understanding the Aspiration to Stay: A Case Study of Young Adults in Senegal. International Migration Institute Working Papers 107.

Sik, E. - Szeitl, B. (2016): Migration Intentions in Contemporary Hungary. In: Blaskó, Z. - Fazekas, K. (eds): The Hungarian Labour Market 2016. Budapest: Institute of Economics, Centre for Economic and Regional Studies, Hungarian Academy of Science, pp. 55-59.

Simon, H. A. (1972): Theories of Bounded Rationality. In: McGuire, C. B. - Radner, R. (eds): Decision and Organization. Amsterdam: North-Holland Publishing Company, pp. 161-176.

Simon, H. A. (1990): A Mechanism for Social Selection and Successful Altruism. Science 250: $1665-1668$.

Simon, H. A. (1993): Altruism and Economics. AEA Papers and Proceedings 82(2): 156-172.

Sjaastad, L. A. (1962): The Costs and Returns of Human Migration. Journal of Political Economy 70(5): 80-93. 
Speare, A. J. (1974): Residential Satisfaction as an Intervening Variable in Residential Mobility. Demography 11(2): 173-188.

Sprenger, E. (2013): The Determinants of International Migration in the European Union: An Empirical Analysis. IOS Working Papers 325.

Todaro, M. P. - Maruszko, L. (1987): Illegal Migration and US Immigration Reform: A Conceptual Framework. Population and Development Review 13(1): 101-114.

UN (2017): International Migration Report 2017. New York: United Nations.

Wildasin, D. E. (1989): Interjurisdictional Capital Mobility: Fiscal Externality and a Corrective Subsidy. Journal of Urban Economics 25: 193-212.

Zaiceva, A. - Zimmermann, K. F. (2008a): Scale, Diversity, and Determinants of Labour Migration in Europe. Oxford Review of Economic Policy 24(3): 428-452.

Zaiceva, A., - Zimmermann, K. F. (2008b): Scale, Diversity, and Determinants of Labour Migration in Europe. IZA Discussion Paper No. 3595. 


\section{APPENDIX}

Table A1. Descriptive statistics

\begin{tabular}{|c|c|c|c|c|c|}
\hline Variable & Observations & Mean & Std. Dev. & Min & Max \\
\hline \multicolumn{6}{|l|}{ Dependent variable } \\
\hline Migration intention & 26602 & .1363807 & .3431988 & 0 & 1 \\
\hline \multicolumn{6}{|l|}{ Independent variables } \\
\hline Loyaltylcountry & 26520 & 3.54868 & .630651 & 1 & 4 \\
\hline Loyalty\city & 26527 & 3.376371 & .7580354 & 1 & 4 \\
\hline Living with partner & 26571 & .0925069 & .2897456 & 0 & 1 \\
\hline Single & 26571 & .1943096 & .3956757 & 0 & 1 \\
\hline Divorced & 26571 & .0745173 & .2626159 & 0 & 1 \\
\hline Widow & 26571 & .0905498 & .2869733 & 0 & 1 \\
\hline Children & 26602 & .4465078 & .8812927 & 0 & 14 \\
\hline Minority & 21132 & .0998012 & .2997419 & 0 & 1 \\
\hline Age & 26602 & 47.97042 & 18.20096 & 15 & 97 \\
\hline Homeowner & 26602 & .5281182 & .4992181 & 0 & 1 \\
\hline Homeowner with mortgage & 26602 & .231975 & .4221011 & 0 & 1 \\
\hline Education & 26088 & 18.81923 & 5.087374 & 0 & 90 \\
\hline Language & 26518 & .4530508 & .4978003 & 0 & 1 \\
\hline Internet & 26602 & 3.523682 & 2.530618 & 0 & 6 \\
\hline Network \relatives & 26525 & .3295005 & .4700407 & 0 & 1 \\
\hline Network $\backslash$ friends & 26522 & .4529824 & .4977938 & 0 & 1 \\
\hline Network/work & 26552 & .1402531 & .347256 & 0 & 1 \\
\hline Network\study & 26557 & .0809203 & .2727178 & 0 & 1 \\
\hline Network \live & 26556 & .1056258 & .3073639 & 0 & 1 \\
\hline Network〉go & 26523 & .2126456 & .4091867 & 0 & 1 \\
\hline Financial status & 25974 & .3975129 & .4893931 & 0 & 1 \\
\hline Male & 26602 & .4608676 & .4984757 & 0 & 1 \\
\hline Small town & 26582 & .3544128 & .478344 & 0 & 1 \\
\hline Large town & 26582 & .2818449 & .4499066 & 0 & 1 \\
\hline Unemployed & 26602 & .1641982 & .3704623 & 0 & 1 \\
\hline Retired & 26602 & .2877227 & .4527097 & 0 & 1 \\
\hline Student & 26602 & .082287 & .2748067 & 0 & 1 \\
\hline Employed & 26602 & .3943313 & .4887158 & 0 & 1 \\
\hline
\end{tabular}

Source: author's calculations based on European Commission (2012).

Open Access. This is an open-access article distributed under the terms of the Creative Commons Attribution 4.0 International License (https:/creativecommons.org/licenses/ by/4.0), which permits unrestricted use, distribution, and reproduction in any medium, provided the original author and source are credited, a link to the CC License is provided, and changes - if any - are indicated. (SID_1) 